\title{
Sociocultural Adaptation of Labor Migrants: Factors and Prospects
}

\author{
Anatoly V. Klyuev ${ }^{1}$, Kristina O. Palamarchuk ${ }^{2}$ \\ ${ }^{1}$ Russian Presidential Academy of National Economy and Public Administration (North-West Institute \\ of Management, RANEPA), St. Petersburg, Russian Federation; klyuev-av@ranepa.ru \\ ${ }^{2}$ The Administration of the Governor of Saint-Petersburg, St. Petersburg, Russian Federation
}

Клюев А. В. ${ }^{1}$, Паламарчук К. О. ${ }^{2}$

${ }^{1}$ Российская академия народного хозяйства и государственной службы при Президенте Российской Федерации (Северо-Западный институт управления РАНХиГС), Санкт-Петербург, Российская Федерация; klyuev-av@ranepa.ru

${ }^{2}$ Администрация Губернатора Санкт-Петербурга, Санкт-Петербург, Российская Федерация

\begin{abstract}
Migration is a complex social process, which is not limited to territorial movement. It includes economic, labor, psychological, cultural and other aspects. In this regard, adaptation processes are an important goal of the study. They can be either successful or unsuccessful. It depends on many conditions that are classified into external and internal. The aim of the article is to analyze these factors affecting the adaptation process. The study of subjective factors of adaptation is associated with the internal motivation, attitudes, goals and motives of migrants moving in another country. The article focuses on the steps and levels of migrants integration in the host society. The determining influence on the dynamics of adaptation processes is provided by migration policy that regulates migration flows. The adaptation process itself seems either multilevel, progressive, otherwise it ends at some stage. The purpose of the article is precisely to reveal the passage of adaptation steps and levels, mainly of labor migrants located in Russia.
\end{abstract}

Keywords: migration, adaptation, acculturation, migration process, migrants

For citing: Klyuev A. V., Palamarchuk K. O. Sociocultural Adaptation of Labor Migrants: Factors and Prospects // Administrative consulting. 2020. No. 7. P. 37-45.

Для цитирования: Klyuev A. V., Palamarchuk K. O. Sociocultural Adaptation of Labor Migrants: Factors and Prospects // Управленческое консультирование. 2020. № 7. С. 37-45.

\section{Research methods}

Ethnic and migrant groups are the most complex objects of sociological research because of their social exclusion. This is expressed in a certain isolation of ethnic diasporas, migrant enclaves, etc. Sociological methods are widely used in the study of integration processes. This article uses methods developed by the Chicago School of Sociology, which include quantitative and qualitative tools. The expert method turned out to be very productive, which made it possible to elicit the opinion of specialists in the field of migration on the complex problems of various migrant groups adaptation, as well as content analysis. The questionnaire method with a small sample set was used. The topic of the article does not involve mass polls: it's aimed at studying motivational orientations and conditions, inclusion mostly of labor migrants in the new social environment and adaptation to it.

The experts interviewed included representatives: Charity Fund for Support and Development of Educational and Social Projects "PSP-Fund", St. Petersburg Regional Branch of the All-Russian Public Organization "Russian Red Cross", Autonomous NonProfit Organization of Socio-Cultural Programs and Projects "Children of St. Petersburg", 
executive body of St. Petersburg (officials of the Committee on Interethnic Relations and the Implementation of the Migration Policy of St. Petersburg, the Committee on Labor and Employment of the Population of St. Petersburg), St. Petersburg State Autonomous Institution "Center of manpower", St. Petersburg State breech Institution "St. Petersburg House of Nationalities", St. Petersburg University of the Ministry of Interior of Russia.

\section{Theoretical and Methodological Provisions}

Migration as a natural process takes place throughout the history of mankind, but it takes on a large-scale character in the $X X-X X I$ century. This is due to industrialization trends and socio-economic processes globalization.

In addition to globalization, the more specific reasons for the growth of migration rates include a gap in the level of socio-economic development of different countries. For citizens of countries with a low level of development, economically developed countries that have more opportunities for life become attractive.

The Russian Federation is a country in need in foreign labor and host migrants. For her, labor migration is more in demand, with an emphasis on unskilled labor. Although it should be noted that the analysis of changes in the legal framework revealed a shift in the vector of migration policy in Russia from low-skilled migrants to those with professional training. The migration policy of Russia declares the need to attract migrants and especially skilled, creating legal grounds for this, as well as the migration policy of any state that uses migration resources [23].

As an example, we give the Order of the Ministry of Labor of Russia dated December 16, 2019 N 791n "On the distribution among the constituent entities of the Russian Federation of quotas approved by the Government of the Russian Federation for 2020 for issuing foreign citizens arriving in the Russian Federation on the basis of a visa, work permits and invitations to enter The Russian Federation for the purpose of carrying out labor activity", Order of the Ministry of Labor of Russia dated December 27, 2019 N 834 "On approval of the list of professions (specialties, positions) for attracting foreign workers arriving in the Russian Federation on the basis of a visa, for 2020" etc.

A comparative analysis showed that in the list of quotas for 2020 the share of foreign workers in certain sectors, for example, the transport sector, was reduced. The resolution was approved in the Russian legal framework in relation to foreign citizens. The percentage of foreign workers in the economic sectors is reviewed annually, taking into account the market characteristics of the constituent entities of the Russian Federation, as well as the demand, primarily, for jobs for Russian citizens.

However, the direction to invite specialists has only a tendency to development. In the Russian Federation as a whole and in particular in St. Petersburg, the number of low-skilled migrants continues to prevail [16, p. 277].

This fact is confirmed as experts in the field of work with migrants, who estimate that a significant part of migrants occupy low-skilled jobs, as well as statistical data provided by the St. Petersburg State Autonomous Institution "Labor Center".

According to work-based data provided by the Center with labor migrants and their employers, the quantitative indicators of labor migration over the past 5 years remain at the same level (230-270 thousand migrants). In the example of 2018 , we consider the areas of employment by which migrants are distributed. ( $88 \%$ of the total number registered at the Center were predominantly employed in the low-skilled sphere).

Thus, from an economic point of view, the demand for Russia in a foreign workforce with different qualifications is very obvious. It is necessary to consider labor migrants not only from the point of view of production feasibility, but also as potential social 
The scope of employment of labor migrants in St. Petersburg in 2018

\begin{tabular}{|l|r|c|}
\hline \multicolumn{1}{|c|}{ Name of the enlarged group of employment } & \multicolumn{2}{c|}{2018} \\
\cline { 2 - 3 } & pers. & $\%$ \\
\hline Unskilled construction and industry workers & 60413 & 21,8 \\
\hline Unskilled workers in housing and communal services & 31207 & 11,3 \\
\hline Woodworking professions & 26060 & 9,4 \\
\hline Unskilled workers in trade and services & 24042 & 8,7 \\
\hline $\begin{array}{l}\text { Technical employees involved in the preparation and accounting } \\
\text { of information, documentation }\end{array}$ & 23382 & 8,4 \\
\hline Other professions that do not require training & 19431 & 7,0 \\
\hline $\begin{array}{l}\text { Industrial and civil engineering technicians with secondary } \\
\text { vocational education }\end{array}$ & 16746 & 6,0 \\
\hline Catering professions & 14285 & 5,2 \\
\hline Administrative staff with secondary vocational education & 8677 & 3,1 \\
\hline Food industry professions & 8317 & 3,0 \\
\hline Professions of transport & 6657 & 2,4 \\
\hline Health care professionals with secondary vocational education & 5518 & 2,0 \\
\hline Total & 244735 & 88,3 \\
\hline
\end{tabular}

capital, a sub-institution of primary human or economic capital with a tendency to further incorporation into a new social environment [18, p. 116-118].

In the article by O.L. Proskuryakova "Adaptation of migrants as a social process" noted that social adaptation means a form of adaptation of an individual or social group to the surrounding social environment [17, p. 59]. The author analyzes the concept of "social adaptation" in relation to the social group of migrants, which allowed to determine its structure, as well as to identify internal and external factors that affect the structure of the adaptation process.

The adaptation process of migrants is multi-stage and multi-level, can be characterized as integrative, but not always progressive, with a transition from one level to another. It can persist at any one stage.

The inclusion of migrants in a new society for them is a long evolutionary process, depending on many factors: employment opportunities, social conditions, the attitude of the local population towards migrants, socio-economic situation, etc.

The process of integration into the host society depends not only on favorable conditions in a foreign environment (although this is important), but also on the motivational component and previously established social attitudes.

The socialization of migrants is based on the perception of social norms, social and cultural values of the host society. A promising prerequisite for the integration of migrants is their orientation to a long period of stay in Russia and their intention to obtain Russian citizenship.

It is important to note that obtaining citizenship by migrants does not mean their final integration into society, since they retain their attitudes and stereotypes. For example, for former migrants, possession of French citizenship automatically means inclusion in French culture, recognition of fidelity to French values. However, Muslim neighborhoods live their own lives, according to their laws and traditions. The integration of migrants reflects not so much its sequence as the staged versatility and depth of this process. 
In our opinion, an indicator of integration into the new society is the formation of sustainable social ties at different levels in the host society: both with individuals and institutions (official institutions)

\section{Results}

A sociological approach to the study of migration processes, focusing on the problems of adaptation and integration of migrants, widely represented in the works of both foreign and Russian researchers (W. Thomas and F. Znanetsky [24], R. Park [22], A. S. Akhiezer [1; 2], A. V. Dmitriev [8], A. G. Zdravomyslov [9], M. N. Guboglo [6; 7] and others).

Migration processes are also studied from the perspective of the emergence of migration risks that are directly related to the theory of social integration. So, in 2000 , the theory of social integration (Harmut Esser [19]) was developed. It was improved by Friedrich Hekman [20, p. 69-70, p. 181-182] in 2015: the theory is based on the difference in systemic and social integration, introduced by the British sociologist David Lockwood in 1964.

It should be noted that in the 2000 a number of scientists (for example, R. Brubaker [3, p. 235-237]) presented an altered understanding of the term "assimilation", originally formed by M. Gordon [21]. Within the framework of this approach, the dominant topic for study is the problems of adaptation and integration of migrants in the new society: cultural and ethnic environment. This or that social space will be more or less attractive depending on the migration experience of previous generations of ethnic groups, the presence of friendly ties of fellow countrymen living in a given period of time.

According to the author's approaches, a different classification is given to the processes of social integration. For example, H. Esser identifies four forms of social integration: acculturation, positioning, interaction, identification, on the basis of which F. Hekman formulates and operates with such concepts as cultural, structural, interactive and identification integration. [20, p. 69-83]. It should be noted that there are different variations of acculturation regarding the interaction of ethnic cultures. For example, V. Malakhov noted the term "integration of migrants" often implies assimilation, cultural adaptation, structural adaptation [13, p. 32]. These terms are not synonymous. They indicate that the integration of migrants is a complex phenomenon that affects various aspects of their lives. Without dwelling on the terminological specifics, we believe that acculturation is the highest level of integration, which is characterized by a high level of ethnocultural tendencies and can be carried out subject to counter flows, both from the side of migrants and the receiving side. Here, a large role belongs to the carriers of the basic culture, capable of perceiving the culture of the arriving ethnic groups, which in turn should be ready to adapt to it. Acculturation as the most high-quality sociocultural process takes a long period of time. We focus on the initial phases of the integration of predominantly labor migrants taking into account Russian conditions, that is, on adaptation processes, which includes several levels [10, p. 349].

The first level of adaptation is more typical for those labor migrants who are focused only on earning and mastering basic norms of behavior with the employer and the migration services.

This level of adaptation is characterized by the fact that social contacts of migrants are carried out mainly within their ethnocultural diaspora and with the employer on organizational and production issues.

Thus, entry into the cultural space of the host society practically does not occur, but parallel spaces arise to satisfy cultural and domestic needs within their ethnic enclaves.

The second level of the socio-cultural process reflects the state of adaptation of migrants and is understood as the adaptation of legal migrant workers to the host society. 
The real manifestation of this process is communication with the local population in Russian and the desire to master labor skills in a specific field of activity, which is caused by the need to consolidate their labor status.

A clarifying concept of the considered level of sociocultural adaptation is accommodation, which in literal translation from Latin means "adaptation", "adaptation".

According to experts, it depends on many reasons and, in particular, not so much on the fact that they do not want to adapt to the host community, but rather on the fact that the institutions of socialization, adaptation and integration of migrants are ineffective today, which is partly due to insufficient regulatory, legal regulation and lack of a structured system.

The third level of the sociocultural process, which takes a longer period of migrants in a foreign cultural environment, is called separate, associated with a real attempt to find certain interactions in the field of the culture of the host society and the cultural norms of migrants, initially functioning separately and, possibly, contradicting each other [14, p. 47].

Under the condition of various external and internal factors that influence integration trends, its subject is the migrants themselves, who have a certain potential. The analysis allows us to draw a fairly general conclusion that the newcomers in their mass do not have sufficient readiness to adapt for certain reasons. We can say that, relatively speaking, they are at the zero level and they have to go through different stages of the adaptation process.

So, in the conditions of Russian society, there are the following conditions that impede the adaptation of migrants to this society.

Firstly, migrants are a heterogeneous mass: they differentiate in terms of education, training, purpose of arrival, and are also representatives of different socio-demographic groups, ethnic groups, and religious groups.

Secondly, new cohorts of foreign citizens coming to local labor markets, most often coming from traditional patriarchal societies, with a different culture, different norms and values, and other rules of behavior.

Thirdly, the inevitable increase in the ethnocultural diversity of the regions, the "erosion" of the existing ethnosocial composition of the population create the preconditions for confrontation between the local population and migrants.

Today, the relationship between the host society and visitors is far from ideal.

Fourthly, some foreign ethnic migrants ignore the norms and traditions of behavior in the host community. Areas of ethnic settlements in rural areas and in cities are being created.

Fifth, the remoteness of territories and differences in culture, the development of social infrastructure, the climatic and geographical position of Russia and donor countries (Uzbekistan, Tajikistan, etc.) determine the existing difference in religious, cultural traditions and everyday life of the host community of migrants.

Sixth, the migrant socioculture itself is very amorphous and is based mainly on ethnocultural traditions and elements of a subculture acquired in a social Russian environment that is foreign to them.

Seventh, in modern conditions at the state level, serious attention is paid to the shortcomings of the state migration policy. In particular, it is said that existing migration rules are not sufficiently clear and unified. The level of application of information technology in the provision of public services and the implementation of state control in the field of migration remains low.

The main factors contributing to the integration of migrants in Russian society, based on real practice, we can name the following: regulatory, family, organizational and others.

First of all, attention should be paid to improving regulatory factors. As already noted, we are talking about reforming migration policy. On March 6, 2020, the 
President of the Russian Federation V. V. Putin approved a list of instructions to implement the concept of state migration policy for the next six years, which proposes: to reform the work of migration regimes and the institution of citizenship of the Russian Federation, to ensure the adjustment of the action plan for the implementation in 2019-2021 of the Concept of state migration policy of the Russian Federation for 2019-2025.

At present, discussion and development of the Migration Code as a single regulatory document governing migration processes and relations arising in this area is also underway.

Improving the legal framework can allow more efficient management of migration processes in the interests of the state, society and migrants themselves, who face various problems, and are also often poorly integrated into the host community.

When answering an interview question about what a complex of measures aimed at social adaptation and integration of migrants in Russian society includes, experts noted that there is virtually no legal basis for operating with the terms "adaptation" and "integration" in the official spirit. Over the past nine years, the development of the Federal Law of the Russian Federation.

"On the social and cultural adaptation and integration of foreign citizens in the Russian Federation", containing the necessary legal terms.

Actual lack of legislation in this direction, with regard to immigrants it does not allow to freely use the proposed terms and talk about the formation and development of a system on the basis of developed regulatory legal acts, while activities in this area are carried out in the framework of the implementation of program documents. Of course, despite the absence of legislatively fixed norms, work in this direction is being carried out.

According to the migration policy, the following areas have been identified for the integration of migrants:

- creating favorable conditions for resettlement to the Russian Federation and obtaining, if desired, Russian citizenship by persons who speak the Russian language and are close to us in mentality and culture;

- the formation of understandable migration rules both for people who are ready to choose the Russian Federation as a new place of residence, and for those who come to us for a while, as a tourist, for work, study or for other purposes;

- increasing the level of security, including through the wider introduction of modern information technologies in the provision of public services and state control. To maintain social stability and prevent conflicts on ethnic grounds, it is necessary to take into account the national structure of migrants arriving in the country when implementing state policy [12, p. 56].

The family factor (poorly understood) includes the influence of the family on the process of integration of migrants in Russian society. It is noted that during a family move, the likelihood of focusing on permanent residence in the future increases, since each member of the family makes certain social ties that will contribute to successful integration in the future. Within migrant families tendencies may develop over a long period of stay in Russia with the prospect of obtaining citizenship.

This is due to the fact that family members at different levels form social ties. The device of life and inclusion in the social environment, the formed network of social interaction contribute to a long stay in Russia. The younger generation integrates through educational institutions, the older generation through job placement. Non-working family members (mainly women) who are less integrated into the host society receive little attention. During the expert survey, information was received on what problems migrants who come with their families most often face. In addition to employment, the following come to the forefront: the high cost of housing, the receipt of medical care (the high 
cost of a medical insurance policy), the placement of children in the organization of the educational system (preschool and general education), etc.

Over the past five years, significant changes have occurred in the structure of work with labor migrants and members of their families in St. Petersburg. So, in addition to the general structuring of the work system the direction of differentiated work with migrants has developed significantly: with labor migrants, their children (if in 2012-2013 such a question was just beginning to be considered by leading experts, then in 2019 work with children has already been formed and is being established, which, however, requires further scaling and improvement), the foundations are laid for the formation of work with women who are not engaged in labor activities. Which, of course, is important, since there has been an increase in the number of women and minor children in the migration structure [15, p. 920].

The recorded increase in the number of women among the total number of migrants is due to the fact that the initial goal of migration is often to accompany a spouse.

School children staying on the territory of Russia often do not have acceptable knowledge of the Russian language, necessary for general education. In this regard, children face problems in mastering the school curriculum. In most cases, their parents do not have the necessary financial resources to pay for tutors. In the case of a large concentration of such children in a classroom or school, it is possible to form their closed group, poorly integrated into communication with the host society.

During the interview, the experts also noted that today a number of cultural events have been organized that contribute to the inclusion of migrant children in society by the State Treasury: the St. Petersburg House of Nationalities and narrowly a specialized representative of the non-profit sector, the public organization Children of Petersburg, which organizes courses in the Russian language and culture, as well as classes in other relevant academic subjects, etc.

Interaction with representatives of the city's district administrations and local governments allows us to identify schools and classes with the highest concentration of migrant children and possible conflict situations due to the closeness of children and low levels of inclusion in society.

An important factor affecting integration processes is organizational.

An example is the organized recruitment of migrants. The organized recruitment algorithm includes the following main stages: an application for the recruitment of necessary workers from the employer and an application for the search for suitable work in St. Petersburg from a foreign citizen who indicates his professional knowledge, skills, work experience, etc.; checking candidates for the presence of a ban on entry into the Russian Federation, searching for suitable jobs and selecting the necessary workers based on an analysis of databases of vacancies and job seekers [11, p. 145]. A targeted, organized recruitment of migrants can be characterized as selective.

This is a focused process of attracting foreign workers to Russia, which is regulated by relevant legal acts, for example, such as:

Decree of the Government of the Russian Federation dated December 3, 2019 N 1579 "On determining the need to attract foreign workers arriving in the Russian Federation on the basis of a visa, including for priority vocational qualification groups, and approval of quotas for 2020"; Order of the Ministry of Labor of Russia dated December 16, 2019 N 791n "On the distribution among the constituent entities of the Russian Federation of quotas approved by the Government of the Russian Federation for 2020 for the issuance of foreign citizens arriving in the Russian Federation based on visa, work permits, and entry invitations to the Russian Federation for the purpose of labor activity", Order of the Ministry of Labor of Russia dated December 27, 2019 N 834 "On approval of the list of professions (specialties, positions) for attracting foreign workers arriving in the Russian Federation on the basis of a visa, for 2020". 


\section{Conclusion}

Thus, labor migration in Russia is considered at the present stage, as one of the resources for replenishing the workforce, i.e., the able-bodied population, under the conditions of the tendency of depopulation of the Russian population. However, from the perspective of the socio-economic development of civil society, this does not mean only a simple increase in the population as a temporary workforce due to its mechanical growth. An important stage nevertheless is the sociocultural adaptation associated with the demand for migrants. Acculturation of migrants can concern only a small part of them. Today we can assume that this process will take a fairly long period of time, with the prospect of a qualitative, selective result.

Significant adaptive potential is possessed only by those groups of migrants who are focused on a long stay in Russia, speak the Russian language, are in constant contact with the local population, are ready to do any job, have professional skills and respect the Russian culture and its traditions.

Today it can be said that 4-12 percent of migrants are fully integrated, about 7 percent are in the integration process (V. Mukomel). Given the differentiation of different immigrant groups, their target behavioral attitudes, the specifics of ethnic culture, etc. it is necessary to develop and implement socially adaptive forms and mechanisms of socialization of migrants, as well as ensuring social security [13, p. 47].

Also, when developing various legal documents, adaptation and integration programs, it is advisable to turn to the experience of other countries that have encountered a solution to this issue with an increase in migration flow. Different countries use different tools for the quality integration of migrants. Work is being done both with migrants and with the host society [4].

\section{References}

1. Akhiezer A.S. Dialectics of urbanization and migration in Russia // Social Sciences and the Present [Obshchestvennye nauki i sovremennost']. 2000. N 1. P. 78-89. (In rus)

2. Akhiezer A. S. Migration in Russian history // Politia [Politiya]. 2004. N 4. P. 69-76. (In rus)

3. Brubaker R. Ethnicity without groups / translate from English; National researched University "Higher School of Economics". M. : Publishing House Higher School of Economics, 2012. (Social Theory). (In rus)

4. Warsaw E. Twenty successful practices of migrant integration. MISKP, 2014. (In rus)

5. Grigoriev D.S. An analysis of the relationship of the multicultural ideology of J. Berry and the various principles of interethnic categorization // Bulletin of Moscow University. Ser. 14. Psychology [Vestnik moskovskogo universiteta. Ser. 14. Psikhologiya]. 2017. N 4. P. 54-64. (In rus)

6. Guboglo M. N. Identity Identification. Ethnosociological essays. M.: Nauka, 2003. (In rus)

7. Guboglo M.N. To the study of identities. Questions of theory // Ethnic mobilization and interethnic integration. M., 1999. P. 265-303. (In rus)

8. Dmitriev A. V. Conflictogenicity of migration: theoretical and practical problems // Sociological science and social practice [Sotsiologicheskaya nauka i sotsial'naya praktika]. 2015. N 1. P. 16-29. (In rus)

9. Zdravomyslov A.G. National identity of Russians // Monitoring of public opinion [Monitoring obshchestvennogo mneniya]. 2002. N 2 (58). P. 48-54. (In rus)

10. Klyuev A.V. Processes and stages of adaptation of migrants in modern Russian society // Scientific works of the North-West Institute of Management of RANEPA [Nauchnye trudy SeveroZapadnogo instituta upravleniya RANKhiGS]. 2015. Vol. 6. Is. 2 (19). P. 261-179. (In rus)

11. Klyuev A. V., Nemtsova A. N. Real and potential prospects for the inclusion of labor migrants in the labor market // Administrative Consulting [Upravlencheskoe konsul'tirovanie]. $2016 \mathrm{~N} 9$. P. 141-147. (In rus)

12. Lipatova L. N. Gradusova V. N. Migration of the population in the context of economic security and social stability // Administrative Consulting [Upravlencheskoe konsul'tirovanie]. 2020. N 1 . P. 56-72 (In rus) 
13. Malakhov V. S. Integration of Migrants: Concepts and Practices. Moscow : Fund "Liberal Mission", 2015. (In rus)

14. Mukomel V.I. Integration of migrants: challenges, politics, social practices // World of Russia [Mir Rossii]. 2011. N 1. P. 34-49. (In rus)

15. Palamarchuk K. O. Social adaptation of women migrants in St. Petersburg (Russia) and Turku (Finland), Russian Sociological Community: history, modernity, place in world science // Materials of scientific conference on the 100th anniversary of the Russian Sociological Society named after M. M. Kovalevsky. November 10-12, 2016. / Ed. Yu. V. Asochakov. SPb. : Scythia-Print, 2016. P. 919-921. (In rus)

16. Palamarchuk K.O. Trends and prospects for the development of migration in an urbanized environment (for example of St. Petersburg) // State and municipal administration. Scientific notes [Gosudarstvennoe i munitsipal'noe upravlenie. Nauchnye zapiski]. 2019. N 2. P. 274-277. (In rus)

17. Proskuryakova O.L. Adaptation of migrants as a social process // Bulletin of the Orenburg State University [Vestnik Orenburgskogo gosudarstvennogo universiteta]. 2007. N 4. P. 58-63. (In rus)

18. Coleman J. Social Capital in the Creation of Human Capital // The American Journal of Sociology. 1988. Vol. 94. P. 95-120.

19. Esser H. Soziologie. Spezielle Grundlagen. Band 2: Die Konstruktion der Gesellschaft. Frankfurt / M., 2000; Esser H. Soziologie. Spezielle Grundlagen. Band 5: Institutionen. Frankfurt / M., 2000.

20. Heckmann F. Integration von Migranten. Einwanderung und neue Nationenbildung. SpringerVerlag, 2014. $309 \mathrm{~s}$.

21. Gordon Milton M. Assimilation in American Life: The Role of Race, Religion, and National Origins. N. Y., 1964.

22. Park R., Burgess E., McKenzie R. The city: suggestions for the investigation of human nature in the urban environment. Chicago, 1925.

23. Satvinder S. J. International Migration And Global Justice (Law and Migration). N. Y. : Ashgate Publishing, 2006.

24. Thomas W., Znaniecki F. The Polish peasant in Europe and America: In 2 Vol. N. Y., 1958.

About the authors:

Anatoly V. Klyuev, Director of the Center for Sociological Research of North-West Institute of Management, Branch of RANEPA (St. Petersburg, Russian Federation), Doctor of Science (Philosophy), Professor; klyuev-av@ranepa.ru

Kristina O. Palamarchuk, Specialist of the Control and Methodological Department of the Citizens' Requests Office of the Administration of the Saint Petersburg Governor, High-Research teacher (39.06.01 Sociological sciences), ya.morganit@yandex.ru

\section{Об авторах:}

Клюев Анатолий Владимирович, директор Центра социологических исследований СевероЗападного института управления РАНХиГС, Санкт-Петербург, Российская Федерация, доктор философских наук, профессор; klyuev-av@ranepa.ru

Паламарчук Кристина Олеговна, главный специалист контрольно-методического отдела Управления по работе с обращениями граждан Администрации Губернатора СанктПетербурга, «Исследователь. Преподаватель-исследователь» по направлению подготовки 39.06.01 Социологические науки, уa.morganit@yandex.ru 